\title{
KIT Overexpression Positive
}

National Cancer Institute

\section{Source}

National Cancer Institute. KIT Overexpression Positive. NCI Thesaurus. Code C147076.

An indication that overexpression of KIT has been detected in a sample. 